\title{
Freeports: innovative trading hubs or centres for money laundering and tax evation?
}

\author{
Paul Gilmour, University of Portsmouth
}

\begin{abstract}
Purpose - This article provides a critical overview of freeports' trading operations and considers to what extent they may present a money-laundering and tax-evasion risk.
\end{abstract}

Design/methodology/approach - This study reviews the literature surrounding freeports and offers an up-to-date narrative of their potential money-laundering and tax-evasion activities. The paper relies on secondary data from published sources referencing peer-reviewed articles and 'grey-literature' material relating to freeports, offshore finance, and anti-money laundering control.

Findings - This study demonstrates the attractive trading advantages offered by freeports to enable enterprise and innovation. However, the article reveals that the secretive offshore space in which freeports operate also helps to obscure beneficial ownership and illicit trade-based practices that frustrate authorities' efforts to trace laundered monies and recover government taxes. Despite freeports' trade offerings, stronger regulation is needed to prevent them being abused for money-laundering and tax-evasion purposes.

Originality/Value - This study provides an important insight into the moneylaundering and tax-evasion risks presented by freeports and, in doing so, advances the contemporary debate on illicit activities occurring through offshore jurisdictions. 
Keywords: freeport; free-trade zone; offshore; money laundering; tax haven; trade.

\section{Paper type: Research paper}

\section{Introduction}

For many years, there has been an increasing trend for nations to introduce specialised trade zones within its territory free from economic and commercial restraint to invigorate the local economy and maintain fiscal dominance (Hakimian, 2011). This strategy has included establishing onshore zones, known as 'freeports'. Freeports are warehouses located within free-trade zones that lie within a country's geographical border but are designated by that country's government to be outside its normal customs regime (Webb, 2020). Freeports are typically located at nationally strategic hubs, such as air, rail, and seaports, to facilitate trade through the country. Freeports and the companies based within these zones enjoy several concessions, like cheaper import duties, suspended custom obligations, and reduced bureaucratic checks intended to streamline cross-border trade (Moiseienko et al., 2020; Webb, 2020). Therefore, freeports seem to provide innovative trading advantages over other jurisdictions bound by stricter customs obligations and, thus, offer a more attractive environment through which to conduct business.

However, there is concern that economic concessions and reduced regulatory oversight enjoyed by freeports allows criminals to misuse them for illicit purposes. According to Korver (2018), the art market, which relies on freeports for warehousing its goods, can be obscured through nondisclosure of beneficial ownership of assets transiting through international borders. Such secrecy can hinder authorities' attempts to trace and recover illicit proceeds (Gilmour, 2020). Similarly, self- 
declaration practices occurring within freeports lend themselves to fraudulent overor under-invoicing of goods; thus, enabling trade-based money laundering (Korver, 2018). Therefore, the risks associated with freeports must be understood to strengthen anti-money laundering (AML) efforts. Yet, despite freeports' possible benefits for global trade, little research has addressed how freeports might enable money laundering and tax evasion (Lavissière and Rodrigue, 2017).

This article considers freeports' potential to enable money laundering and tax evasion. It highlights several overriding criminal methods that are enabled within freeports' offshore space of regulatory concessions and, therefore, advances the scope in which offshore dealings are judged. This article argues that though freeports present an innovative platform through which successful trade can be enabled and maintained, their misuse for money-laundering and tax-evasion purposes raises justifiable concerns. This article concludes that further government oversight is needed to curb illegal activity through freeport zones.

\section{What are freeports?}

The idea of freeports being hubs relatively free of trading regulation has been long established: the first modern economic freeports were established at strategic SouthEast Asian sea- and airports throughout the late 1960s (Sellick, 2020). Many freeports operate around the world, though, some of the most prominent now specialise in the storage of fine art, such as those in Beijing, Switzerland, and Monaco (Steiner, 2017, p. 356). As Steiner (2017, p. 354) has noted, Switzerland's freeports, home to renowned auction houses, are instrumental to the success of the art market that is now worth $\$ 75$ billion globally. However, according to Letzing and 
Colchester (2015), freeports were originally conceived as temporary storage spaces free of taxes while goods were in transit to their onshore destination.

Korver (2018) recognised freeports as tactical depots intended as spaces to temporarily house valuable assets, like artwork, precious metals and gems, wine collections and antiques. However, Weeks (2020, p. 4) has stated that many art dealers now commonly exploit freeports' beneficial goods-in-transit position to house their assets on a more permanent basis. This means, as long as the dealers' goods remain within the freeports' storage facility, those dealers are unaccountable for any duties (such as value-added taxes [VAT] or capital gains taxes) which would normally be applied upon export (Weeks, 2020; see also Schwarzkopf and Backsell, 2020, p. 7). It also means those same goods would not be subject to the crossborder scrutiny of authorities as other exported goods would be. For Weeks (2020), the exploitation of freeports in this way enables illicit activity, such as money laundering and tax evasion.

\section{Freeports: indicators of developing global offshore capitalism?}

Recent scholarship has conceptualised freeports as manifestations of offshore capitalism that has evolved throughout an increasingly globalised society (Lavissière and Rodrigue, 2017; Post and Calvão, 2020; Schwarzkopf and Backsell, 2020). Leyshon and Thrift (1997) argued that an increased mobility of capital across permeable state borders is key to progressive forms of capitalism. They also highlighted two causes of the global proliferation of privately held finance: (1) implementation of flawed fiscal regimes of Western governments that have tried to regulate and control capital; and (2), and the globalisation of monetary supplies and services (Leyshon and Thrift, 1997, p. 74). Post and Calvão (2020, p. 4) argued that 
freeports have arisen from the advent of offshore jurisdictions made necessary to spread and accumulate global wealth "no longer tied to colonial or national spaces". Ogle (2017, p. 1446) similarly viewed the liberation and deregulation of financial markets being pivotal to the development of offshore capitalism. It is within such context that freeports have flourished.

The offshore nature of freeports means that wealthy business clients of luxury art and other assets held in freeport zones can avoid the restrictive regimes of their home countries (Weeks, 2020). For example, Weeks (2020, p. 5) explained how investors managed to avoid restrictions brought in by Germany's 2016 Act on the Protection of Cultural Property that limited trade in antique art valued over $€ 300,000$. Consequently, owners of valuable art chose to shift their assets to freeports in neighbouring Switzerland and Luxembourg before the law was enacted. The dynamic shifts of global capital strengthened by the flexibility offered by freeports suggests freeports help to drive a global offshore-capitalist agenda.

However, literature on freeports has also conceptualised the regulatory space occupied by freeports as being contrary to free-market capitalism. Schwarzkopf and Backsell (2020) have argued that the offshore regulatory model in which freeports operate discourages capital mobility. They explain that the growth in freeports is indicative of a retrograde trend in global capitalism akin to medieval times (Schwarzkopf and Backsell, 2020). This concept seems plausible considering that freeports' beneficial goods-in-transit position provides for assets to remain stored 'in transit' indefinitely - yet goods can be sold and purchased without ever leaving the storage facility and without tax being imposed (Helgadóttir, 2020; Post and Calvão, 2020; Weeks, 2020). Therefore, freeports' legal-spatial paradigm acts to restrict 
capital flow. Such state of perpetuity opposes the liberalised economic policies of many Western governments that advocate freeports.

The following section considers to what extent freeports promote free trade and encourage commercial innovation.

\section{Freeports' benefits for trade and innovation.}

Governments are constantly seeking new ways to boost foreign investment and support their nation's economic prosperity and global trading repute. For instance, a state can bolster its fiscal and technological capability through Foreign Direct Investment [FDI], a process whereby an overseas investor establishes an influential interest within that state's locality (Nketiah-Amponsah and Sarpong, 2020). State governments can also implement legal and practical measures, like tax incentives, and reduced trade barriers, towards attracting enterprise and overseas investment. Such incentives have propelled many areas, like Hong Kong, Singapore, and the Seychelles, to specialise in financial services for non-residents and to become globally dominate Offshore Financial Centres (OFCs; Chan and Lee, 2007). Around 11 per cent of the Seychelles' Gross Domestic Product, for example, derives from overseas investment protected by its attractive financial services market (Mugarura, 2017).

In early 2020 , the UK government published a consultation into proposals to create Freeports across the UK in an aim to stimulate the economy following Brexit. According to the publication, the main purpose of freeports is to facilitate trade and promote innovation and employment (HM Government, 2020, p. 10). Such literature has stated that freeports can promote imports through reduced tax and 
administrative costs and controls (HM Government, 2020). For example, strengthened trade enables manufacturing companies to save on costs of administration and raw ingredients compared to external companies (Stojanovic, 2020). Therefore, freeports act as zones that are advantageous for newly established companies to base their operations as the usual state custom controls, where the zone is geographically located, do not apply.

Companies registered within a freeport benefit from tax relief which supports their capital growth. Also, reduced supervision within freeports provides a more private environment to conduct business and helps companies to better compete internationally (HM Government, 2020). A clear example can be seen with the Middle East, where the Jordanian port of Aqaba, designated a freeport in 1973, became a successful transit hub for trading, further strengthened at the time, by regional oil reserves. Today, the Jebel Ali freeport in the United Arabs Emirates accounts for a fifth of the country's FDI and helps to support over 160,000 jobs ("The role of freezones", 2013). Further, Steiner (2017, p. 355) noted that the area of Geneva in Switzerland has since profited some CHF 10 million each year after a freeport was established there. Such prosperity has helped the area resist the damaging impact of 2008's global financial crisis (Steiner, 2017).

Lavissière and Rodrigue (2017) highlighted freeports' arbitrage advantages. Arbitrage is the procedure in which investors can profit from concurrently buying and selling goods across different international markets. Such practices promote market productivity and maintains freeports' competitive lead over other jurisdictions. It may also mean that nations seeking to remodel their trading links with others (such as, post-Brexit United Kingdom) can still prosper through the freeport model because 
any future trade barriers would potentially further freeports' arbitrage advantages (Lavissière and Rodrigue, 2017).

Nonetheless, the UK Trade Policy Observatory (UKTPO) recently concluded that freeports offer little benefit when a country's trade tariffs are already low (Winters and Holmes, 2020). Holmes (2019) pointed out that freeports do not free goods completely from tariffs - rather, they merely delay duty being imposed until the goods arrive at their destination. The trading benefits of freeports also depend on factors, such as capable labour and access to passage within the freeports (Stojanovic, 2020). Such questions raise doubt over whether freeports really do innovate economic growth. For Stojanovic (2020), freeports simply reroute current initiatives into freeport zones through an allure of tax relief; thus, burdening the taxpayer due to lost government revenue.

Holmes (2019) has argued that to realise any significant long-term benefits in freeports, governments must broaden the incentives that freeports offer (akin to 'enterprise zones'), rather than simply providing short-term duty-free access. For instance, designating the Isle of Dogs in London as an enterprise zone following the demise of the surrounding docks in 1982 provided much needed economic prosperity to the area. The zone gained government support beyond tax breaks, through relaxed development planning rules and improved infrastructure, leading to new employment in the area and neighbouring Canary Wharf (Holmes, 2019). Therefore, expanding freeports' remit to better incentivise the surrounding local economy should be considered. 
The next section explores the primary money-laundering and tax-evasion risks posed by freeports and considers the methods through which such illicit activities occur.

\section{Money-laundering and tax-evasion risks.}

5.1. Freeports help to conceal beneficial ownership.

Contemporary scholarship has argued that the secretive offshore space in which freeports operate helps to conceal beneficial ownership and, thus, promote money laundering and tax evasion (Financial Action Task Force [FATF], 2014; Korver, 2018; Moiseienko et al., 2020; Post and Calvão, 2020). The FATF (2014, p. 8) defined a beneficial owner as,

... the natural person(s) who ultimately owns or controls a customer and/or the natural person on whose behalf a transaction is being conducted. It also includes those persons who exercise ultimate effective control over a legal person or arrangement.

In cases where the true beneficial owner cannot be identified, law-enforcement and tax authorities can find it difficult, if not impossible, to trace illicit proceeds and recover taxes connected to those entities or transactions (Transparency International UK [TI UK], 2017). This issue is compounded by law-enforcement authorities' lack of understanding on the methods criminals use to conceal beneficial ownership using offshore jurisdictions (Gilmour, 2020; Yeoh, 2018; see also FATF, 2018).

Additionally, anonymous shell companies can be used as vehicles to launder money (Le Nguyen, 2018). Shell companies typically have no actual presence apart from a registered address and employ no real people. They create little or 
no independent financial worth and carry out no significant regular commercial endeavours (Gilmour, 2020; Pacini et al., 2019; Pacini and Stowell, 2020). Yet, they can be used to shift assets and substantial amounts of funds worldwide while offering the apparent legitimacy of a registered and fully functioning corporation (Pacini et al., 2019). However, the true beneficial owners of assets tied to those shell companies can remain hidden from interested parties, including the authorities.

The linking of anonymous shell companies to form complex ownership structures can further obscure beneficial ownership and the source of assets based within freeports (Post and Calvão, 2020, p. 9). Pacini and Stowell (2020, p. 374) clarified that shell companies can be linked to various territories reinforcing the corporate structure's anonymity and making it difficult for law-enforcement officials to decipher. This linking of shell companies also enables the corporates better access to global financial markets and to launder illicit money.

Furthermore, freeports' offshore environment helps to distance the beneficial owner of assets from criminality and serves to further complicate illicit corporate structures (FATF, 2018). Steiner (2017, p. 363) explained that it is possible for illicit money to be laundered through the sale of goods stored in freeports, such as artwork. The customer who purchases the art using illicit cash could then store the goods within a freeport without having to disclose the real owner, by simply listing an agent responsible for their disposal on the inventory instead. Importers could also simply self-declare on inventories, providing ample opportunity to falsify invoices and other records to evade taxes and facilitate trade-based 
money laundering (Korver, 2018). Another concern of freeports is the potential they pose in enabling trade-based money laundering.

\subsection{Trade-based money laundering.}

The main purpose of money laundering is to legitimise and conceal criminal profit (Naheem, 2015a; Zali and Maulidi, 2018, p. 44). Money-laundering methods are numerous. Illicit trade-based practices, for example, tend to operate within sophisticated global networks of transactions, which typically challenges domestic AML authorities to a greater degree, compared to other types of money laundering (Stack, 2015, p. 81). Trade-based money laundering (TBML) remains a significant threat to the stability and integrity of the global financial system. FATF (2020, p. 7) reported that the volume of global trade increased by $3 \%$ in 2018 , while the value of global trade reached nearly USD 20 trillion.

The definition of TBML is widely disputed (see Naheem, 2015b; Soudijn, 2014; Sullivan and Smith, 2012). FATF (2006, p. 3) defined it as "the process of disguising the proceeds of crime and moving value through the use of trade transactions in an attempt to legitimise their illegal origin or finance their activities". Naheem (2015b, p. 514) argued that TMBL centres on the dishonest manipulation of trade invoices and freight information to ship goods. However, FATF's (2020, p. 11) recent report clarified that the aim of TBML is to transfer the money enabled by trading, rather than to move goods. Still, such schemes typically involve the misrepresentation of the quality, price, or quantity of imported or exported goods. TBML schemes also involve bogus shipments; multiple invoicing of the same shipment; and other methods to fabricate invoices, transfer funds, or to ship illicit goods, such as drugs and contraband (FATF, 2010; Neale, 2019). Freeports pose particular risk from 
TBML because of the high volume of transactions occurring through freeports, combined with freeports' reduced regulatory supervision (Moiseienko et al., 2020).

Additionally, Neale (2019, para. 18) and Simser (2013, p. 49) agreed that most international trade settlements occur through open merchant accounts. Here, the seller ships the goods and all related business documents to the trusted buyer, who then agrees to pay the seller's invoice later. However, the banks completing the transactions on behalf of the merchants would typically have no awareness of the reasons behind the trade and would not have reviewed the underlying business documentation before processing the transaction (Neale, 2019; Simser, 2013). Arguably, banks are responsible for carrying out customer due diligence, including detecting and reporting suspicious transactions (as obliged by AML laws). Therefore, banks should also know the underlying detail of all global trade transactions that they transact (Neale, 2019).

The European Union's Fifth Anti-Money Laundering Directive (AMLD5), introduced in 2018, amends earlier directives to widen the scope of institutions obliged to follow its rules and now includes freeports. Freeports are required to conduct customer due diligence, report suspicious transactions, and record beneficial ownership information (Helgadóttir, 2020; Korver, 2018; Sellick, 2020). All EU Member States were required to transpose the AMLD's requirements into national law by 10 January 2020 (Council Directive 2018/843/EU, 2018; Sellick, 2020). Freeports are also covered to some extent under the US Foreign Account Tax Compliance Act (FATCA) and the Organisation for Economic Co-operation and Development's (OECD) Common Reporting Standards (Korver, 2018). 
However, freeports are not classified as 'financial institutions' under such regimes and are only regarded as obliged 'non-financial institutions' (Helgadóttir, 2020, pp. 13-14; Korver, 2018, p. 6). This means freeports have no obligation to automatically share information with authorities. Freeports are also not required to inform authorities about the details of private commercial information that they do share (Helgadóttir, 2020). This represents a clear failing of AML rule. Freeports are inherently secret spaces where client confidentiality and discretion provided to businesses operating within freeports is of the upmost importance. Therefore, better transparency of freeports and strengthened laws are needed to combat TBML activities that occur through freeports.

\section{Conclusion.}

This article provides a critical insight into freeports' offshore illicit trading operations. Freeports are innovative trading hubs that provide platforms for invigorating enterprise and economic growth, where businesses can enjoy several economic concessions (Moiseienko et al., 2020; Webb, 2020). Although the growth in freeports may have originally evolved from a desire to stimulate global investment by deregulating financial markets, some argue that freeports' permanent storage spaces only act to stifle capital mobility (Lavissière and Rodrigue, 2017; Ogle, 2017;

Post and Calvão, 2020; Schwarzkopf and Backsell, 2020). Nonetheless, freeports do seem to provide innovative trading advantages to enable businesses to thrive in today's competitive global market (Winters and Holmes, 2020; Holmes, 2019; Stojanovic, 2020).

However, freeports can be abused for money-laundering and tax-evasion purposes. Freeports help to obscure the true beneficial owners of assets through secretive 
corporate practices that thwart authorities' efforts to trace illicit profits and recoup government taxes (FATF, 2014, 2018; Korver, 2018; Le Nguyen, 2018; Moiseienko et al., 2020; Post and Calvão, 2020). Freeports also enable trade-based money laundering by the falsifying of trade invoices to deceive authorities (FATF, 2020). The many international transactions occurring through freeports coupled with freeports' lack of regulatory supervision poses notable challenges for government officials (Moiseienko et al., 2020).

Therefore, further government oversight is needed to curb illegal activity through freeport zones. Banks that facilitate the numerous international trade transactions need to be more alert to illicit trading and responsible for carrying out proper due diligence around freeport transactions (Neale, 2019; Simser, 2013). Although, recent legal regimes recognise the threat that freeports present by incorporating freeports within AML rules, there is still scope for freeports to operate without transparency. This article concludes that despite freeports' trade offerings, stronger regulation is needed to prevent them being abused for money laundering and tax evasion purposes. 


\section{References}

Chan, S. Y-S., \& Lee, J. W. S. (2007), "Tax Incentives in Hong Kong for Offshore Funds and Investment Schemes", International Tax Journal, Vol. 33 No. 6, pp. 1343, https://heinonline.org/HOL/P?h=hein.journals/intaxjo33\&i=339

Council Directive 2018/843/EU. (2018), “Council directive 2018/843/EU of 30 May 2018 on the prevention of the use of the financial system for the purposes of money laundering or terrorist financing, amending Directives 2009/138/EC and 2013/36/EU', Official Journal of the European Union, Vol. L156, pp. 43-74.

Financial Action Task Force. (2006), “Trade-Based Money Laundering”, available at: http://www.fatfgafi.org/media/fatf/documents/reports/Trade\%20Based\%20Money\%20Laundering.p df (accessed 1 January 2021).

Financial Action Task Force. (2010), “Money Laundering vulnerabilities of Free Trade Zones", available at: https://www.fatfgafi.org/media/fatf/documents/reports/ML\%20vulnerabilities\%20of\%20Free\%20Trad e\%20Zones.pdf (accessed 31 December 2020).

Financial Action Task Force. (2014), “FATF Guidance. Transparency and Beneficial Ownership", available at: http://www.fatfgafi.org/media/fatf/documents/reports/Guidance-transparency-beneficialownership.pdf (accessed 21 August 2020). 
Financial Action Task Force. (2018), "Concealment of Beneficial Ownership", available at: $\underline{w w w}$. fatf-

gafi.org/publications/methodandtrends/documents/concealment-beneficialownership.html (accessed 21 August 2020).

Financial Action Task Force. (2020), “Trade-based Money Laundering: Trends and Developments", available at: www.fatfgafi.org/publications/methodandtrends/documents/trade-based-money-launderingtrends-anddevelopments.html (accessed 31 December 2020).

Gilmour, P. M. (2020), "Lifting the veil on beneficial ownership: challenges of implementing the UK's registers of beneficial owners", Journal of Money Laundering Control, Vol. 23 No. 4, 717-734, https://doi.org/10.1108/JMLC-02-2020-0014

Hakimian, H. (2011), “Iran's Free Trade Zones: Back Doors to the International Economy?", Iranian Studies, Vol. 44 No. 6, 851-874, https://doi.org/10.1080/00210862.2011.570525

Helgadóttir, O. (2020), "The new luxury freeports: Offshore storage, tax avoidance, and 'invisible' art", Environment and Planning A: Economy and Space, Vol. 0 No. 0, pp. 1-21, https://doi.org/10.1177/0308518X20972712

Her Majesty's Government. (2020), "Freeports: Response to the Consultation", available at: $\underline{\text { https://www.gov.uk/government/consultations/freeports-consultation }}$ (accessed 08 November 2020). 
Holmes, P. (2019), "Free ports - preparing to trade post-Brexit", available at:

https://blogs.sussex.ac.uk/uktpo/2019/09/26/freeports-preparing-to-trade-post-brexit (accessed 4 December 2020).

Lavissière, A., Rodrigue, J-P. (2017), "Free ports: towards a network of trade gateways", Journal of Shipping and Trading, Vol. 2 No. 7, pp.1-17, https://doi.org/10.1186/s41072-017-0026-6

Le Nguyen, C. (2018), "Preventing the use of financial institutions for money laundering and the implications for financial privacy", Journal of Money Laundering Control, Vol. 21 No. 1, pp. 47-58, https://doi.org/10.1108/JMLC-01-2017-0004

Letzing, J., and Colchester, M. (2015, September 23), "Oligarchs and Orchestras: Inside Luxembourg's Secretive Low-Tax "Fortress of Art" Warehouse". The Wall Street Journal, available at: https://www.wsj.com/articles/art-dealers-woes-putscrutiny-on-high-end-storage-facility-1442857233 (accessed 12 November 2020).

Leyshon, A., and Thrift, N. (1997). Money/Space: Geographies of Monetary Transformation, Routledge, London.

Moiseienko, A., Reid, A., and Chase, I. (2020), “Improving Governance and Tackling Crime in Free-Trade Zones", available at:

https://www.rusi.org/publication/occasional-papers/improving-governance-andtackling-crime-free-trade-zones (accessed 19 October 2020). 
Mugarura, N. (2017), "Tax havens, offshore financial centres and the current sanctions regimes", Journal of Financial Crime, Vol. 24 No. 2, pp. 200-222, https://doi.org/10.1108/JFC-01-2016-0008

Naheem, M. A. (2015a), "Money laundering using investment companies", Journal of Money Laundering Control, Vol. 18 No. 4, pp. 438-446, https://doi.org/10.1108/JMLC-10-2014-0031

Naheem, M.A. (2015b), "Trade based money laundering: towards a working definition for the banking sector", Journal of Money Laundering Control, Vol. 18 No. 4, pp. 513-524, https://doi.org/10.1108/JMLC-01-2015-0002

Neale, D. (2019), "Free Trade Zones: a Pandora's Box for Illicit Money", available at: https://gfintegrity.org/free-trade-zones-a-pandoras-box-for-illicit-money (accessed 31 December 2020).

Nketiah-Amponsah, E., and Sarpong, B. (2020), "Ease of Doing Business and Foreign Direct Investment: Case of Sub-Saharan Africa", International Advances in Economic Research, Vol. 26 No. 3, pp. 209-223, https://doi.org/10.1007/s11294-02009798-w

Ogle, V. (2017), “Archipelago Capitalism: Tax Havens, Offshore Money, and the State, 1950s-1970s", The American Historical Review, Vol. 122 No. 5, pp. 14311458, https://doi.org/10.1093/ahr/122.5.1431 
Pacini, C., Hopwood, W., Young, G., and Crain, J. (2019), "The role of shell entities in fraud and other financial crimes", Managerial Auditing Journal, Vol. 34 No. 3, pp. 247-267, https://doi.org/10.1108/MAJ-01-2018-1768

Pacini, C. and Stowell, N.F. (2020), "Panama Papers and the Abuse of Shell Entities", Baker, H.K., Purda-Heeler, L. and Saadi, S. (Ed.) Corporate Fraud Exposed, Emerald Publishing Limited, pp. 361-382, https://doi.org/10.1108/978-1$\underline{78973-417-120201023}$

Post, E., and Calvão, F. (2020), "Mythical Islands of Value: Free Ports, Offshore Capitalism, and Art Capital”, Arts, Vol. 9 No. 4, pp. 1-19, https://doi.org/10.3390/arts9040100

Schwarzkopf, S., and Backsell, J. I. (2020), "The Nomos of the Freeport", Environment and Planning D: Society and Space, Vol. 0 No. 0, pp. 1-19, https://doi.org/10.1177/0263775820944523

Sellick, J. (2020, October 9), "Where does rural fit in the Government's brand-new Freeport policy?", [Blog] Jessica's Rural Words, available at:

https://ruralwords.co.uk/where-does-rural-fit-in-the-governments-brand-new-freeportpolicy (accessed 12 November 2020).

Simser, J. (2013), "Money laundering: emerging threats and trends”, Journal of Money Laundering Control, Vol. 16 No. 1, pp. 41-54, https://doi.org/10.1108/13685201311286841 
Stack, G. (2015), "Baltic shells: on the mechanics of trade-based money-laundering in the former Soviet space", Journal of Money Laundering Control, Vol. 18 No. 1, pp. 81-98, https://doi.org/10.1108/JMLC-10-2013-0040

Steiner, K. L., (2017), "Dealing with Laundering in the Swiss Art Market: New Legislation and its Threat to Honest Traders", Case Western Reserve Journal of International Law, Vol. 49 No. 1, pp. 351-372, https://scholarlycommons.law.case.edu/jil/vol49/iss1/21

Stojanovic, A. (2020), “Trade: freeports and free zones”, available at the Institute for Government website: https://www.instituteforgovernment.org.uk/explainers/tradefreeports-freezones\#: :text=Economic $\% 20$ studies $\% 20$ have $\% 20$ found $\% 20$ the,to $\% 20$ those $\% 20$ out side\%20the\%20area (accessed 4 December 2020).

Soudijn, M. R. J. (2014), "A critical approach to trade-based money laundering", Journal of Money Laundering Control, Vol. 17 No. 2, pp. 230-242, https://doi.org/10.1108/JMLC-01-2013-0001

Sullivan C., and Smith, E. (2012), “Trade-based money laundering: Risks and regulatory responses", available at SSRN: https://ssrn.com/abstract=2476754 (accessed 31 December 2020).

“The role of freezones". (2013), MEED: Middle East Economic Digest, 7/26/2013 Economic Zones, pp. 6-9. available at: http://search.ebscohost.com (accessed 8 November 2020). 
Webb, D. (2020), "Freeports", House of Commons briefing papers [No. 8823], House of Commons, London, available at: https://commonslibrary.parliament.uk/researchbriefings/cbp-8823/ (accessed 19 October 2020).

Weeks, S. (2020), "A Freeport Comes to Luxembourg, or, Why Those Wishing to Hide Assets Purchase Fine Art." Arts, Vol. 9 No. 3, pp.1-15, https://doi.org/10.3390/arts9030087

Winters, A. and Holmes, P. (2020), "Written response to the Department for International Trade", available at: https://blogs.sussex.ac.uk/uktpo/publications/parliamentary (accessed 4 December 2020).

Yeoh, P. (2018), “Tax Efficient and Tax Secrecy Destinations: Legal, Okay or Not?”, Business Law Review, Vol. 39 No. 2, pp. 34-43,

https://kluwerlawonline.com/journalarticle/Business+Law+Review/39.2/BULA201800

$\underline{9}$

Zali, M., and Maulidi, A. (2018), "Fighting Against Money Laundering”, BRICS Law Journal, Vol. 5 No. 3, pp. 40-63, https://doi.org/10.21684/2412-2343-2018-5-3-40-63 